日臨外会誌 $78(11), 2460-2464,2017$

症例

$$
\begin{gathered}
\text { 腸閉塞を呈した腸管外アニサキス症の } 1 \text { 例 } \\
\text { 水戸赤十字病院外科 }
\end{gathered}
$$

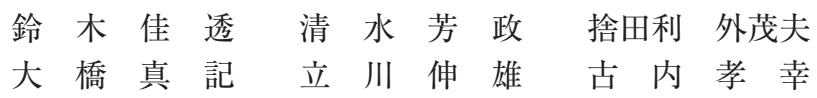

小腸アニサキス症による腸閉塞は比較的多く報告されているが, 今回われわれは, 異 所性アニサキス症による腸閉塞という稀な症例を経験した。 若干の文献的考察を加えて 報告する.

症例は52歳の男性. 入院 2 週間前より発熱・下㾥の症状があり, 入院 3 日前より右下 腹部痛を認め, 当院を受診した. CTで小腸の拡張, 空腸周囲の炎症所見と whirl sign を認め, 腸閉塞の診断で経過観察入院とした. 症状が改善しなかったため, 第14病日に 原因検索, 治療目的に審査腹腔鏡を行った。術中所見では, Treitz鞀帯から $100 \mathrm{~cm}$ の空 腸腸間膜に壁外性の腫瘤を認め, 大網, 腹壁, 腸間膜と癒着を形成していた。この癒着 で形成された空間に, 肚門側の小腸が陥入していた。手術は鏡視下で癒着を切離し小腸 部分切除を施行した。病理結果では, 腸管壁外の好酸球性の化膿性肉芽形成と, 内部に アニサキス幼虫を認め, 異所性アニサキス症と診断した.

索引用語：腸管外アニサキス症, 異所性アニサキス症, 腹腔鏡手術

はじめに

アニサキス症は種々の海産魚介類の生食を原因とす る寄生虫症のうち，最も頻度が高い疾患である ${ }^{1)}$.多 くは胃アニサキス症もしくは腸アニサキス症として発 症するが，極めて稀に腸管壁外まで虫体が穿通し肉芽 種を形成することがあり，これを異所性アニサキス症 という。アアニサキス症による腸閉塞の報告は散見され るが,多くは内㬶の狭窄による閉塞性イレウスである. 今回われわれは，異所性アニサキス症による腸間膜腫 瘤が原因で発症した腸閉塞に対して，腹腔鏡下にイレ ウス解除を行い良好な経過を得た 1 例について報告す る.

患者：52歳, 男性.

\section{症例}

主訴 : 腹痛.

既往歴：特記事項なし.

家族歴：特記事項なし。

現病歴：入院 2 週間前より腹痛が出現し, 近医を受

2017年 7 月25日受付 2017 年 8 月28日採用

〈所属施設住所〉

₹310-0011 水戸市三の丸 $3-12-48$
診し腸炎の診断で抗菌薬加療を受けていた。入院 3 日 前より腹痛が増強し, 改善がそしいため, 当院を紹介 受診. 腸閉塞の診断で精查加療目的に緊急入院となっ た.

入院時現症 : 体温 $36.9^{\circ} \mathrm{C}$, 血圧 $144 / 91 \mathrm{mmHg}$, 脈拍 89回/分. 右下腹部に圧痛を認めたが, 筋性防御, 反 跳痛を認めなかった。

入院時血液検查所見：WBC $15,220 / \mu \mathrm{L}, \mathrm{CRP} 1.03$ $\mathrm{mg} / \mathrm{dL}$, 白血球分画：好中球 $52 \%$, リンパ球 $24 \%$, 単球 $5 \%$, 好酸球 $18 \%$, 好塩基球 $0 \%$, 炎症反応の 上昇と好酸球の軽度增多を認めた。

腹部単純 $\mathrm{X}$ 線検査所見 : 小腸拡張像を認め, niveau を認めた。

腹部造影 $\mathrm{CT}$ 検査所見 : 右下腹部に造影効果を認め る $5 \mathrm{~cm}$ 大の腫瘤影と, 周囲の小腸間膜の浮腫を認め た (Fig. 1a, b).

悪性腫瘍も鑑別に含め, まずは禁食, 補液で加療し た。一時的に症状改善したため, 入院 3 日目に経口摂 取を再開したが, 腹痛・腸閉塞症状が再燃した。 入院 6 日目にイレウス管を挿入した。

イレウス管造影検査所見 : イレウス管の先端は腫瘤 付近に存在していた。消化管造影では造影剤が停滞し 


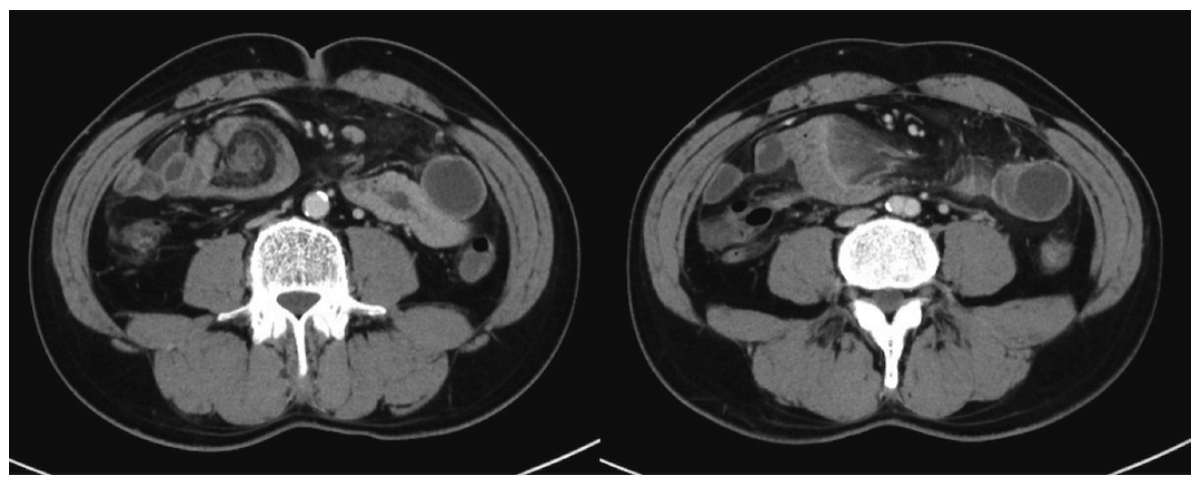

a

$\mathrm{b}$

Fig. 1 Abdominal CT scan showed an intra-abdominal tumor in the right lower quadrant of abdomen ( a ) and edema of intestinal mesentery around the tumor ( b ).

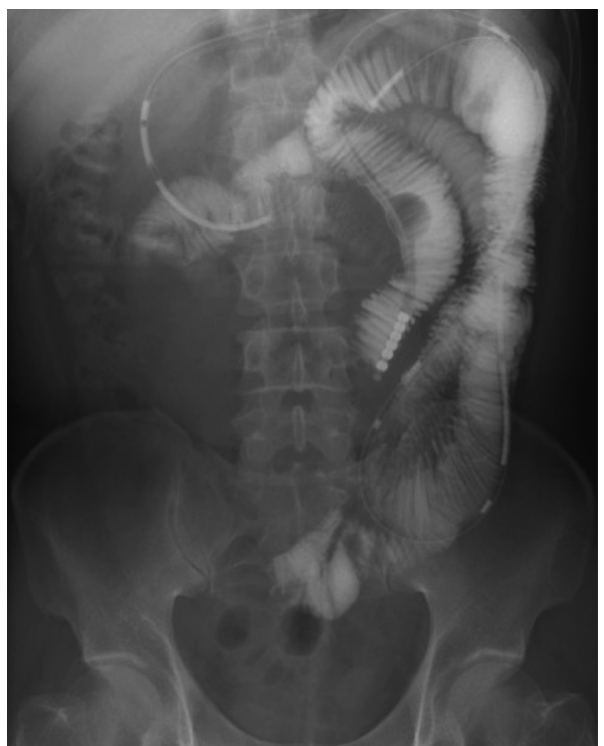

Fig. 2 Tip of a long tube was located by the tumor and contrast radiography of the small bowel showed stagnation of contrast medium.

ているが明らかな beak signは認めなかった (Fig. 2). その後，イレウス管による減圧は良好であったが， イレウス管排液 $500 \mathrm{ml}$ 以上が持続したため, 腫瘤を原 因とする腸閉塞の診断で入院 14 日目に腹腔鏡下手術を 行った。

手術所見：臍部より open methodで12mm ポートを 扦入し, カメラポートとした。次に, 右上腹部・左側 腹部に $5 \mathrm{~mm}$ ポートを挿入し， 3 ポートで手術を開 始した，腸管の拡張は軽度であり，腹水は少量であっ
た。腫瘤は Treitz 鞁帯より $100 \mathrm{~cm} の$ 小腸腸間膜に認 め, 腹壁, 別ループの小腸間膜との間にband を形成し, また大網と瘉着していた。これらで形成された門に肛 門側の腸管が入り込んで拡張していたが，明らかな血 流障害は認めなかった.これらの癒着を切離した上で, 臍部ポート創を延長し，小腸を体外に導出し腫瘤を含 めて小腸部分切除を行い手術終了とした (Fig. 3a, b).

摘出検体： $40 \mathrm{~mm}$ 大の腸間膜腫瘤であり，近傍の小 腸粘膜面には明らかな異常所見を認めなかった（Fig. $4 a, b)$.

病理組織診断：腫瘤は腸管壁外に存在し,内部は好 酸球の強い浸潤を伴う肉芽種を形成していた。内部に アニサキス幼虫の死骸を認め, 腸管外アニサキス症の 診断となった（Fig. 5a, b, c).

術後経過：術後経過は良好で, 術後12日目に退院と した.

\section{考察}

アニサキス症は海産魚介類の生食を原因とするが, 本症例でも後の問診で腹痛発症前日に自ら釣ったイワ シの刺身を搔取していたことが判明している．入院 2 週間前に刺身を摂取した翌日から腹痛が出現していた ことから，その時点で小腸壁内に陥入したアニサキス 虫体が， 2 週間の経過を経て肉芽腫性腫瘤を形成し， 周囲組織との炎症性癒着を原因として腸閉塞を発症し たものと考えられる，病理所見でも腸管壁外，腸間膜 内に好酸球性肉芽腫を形成し，その内部にアニサキス 虫体が同定され，異所性アニサキス症の診断に至った．

アニサキス症の報告の $90 \%$ 以上が本邦からの報告で あり，他国の報告でもほとんどが沿岸地域でのもので 


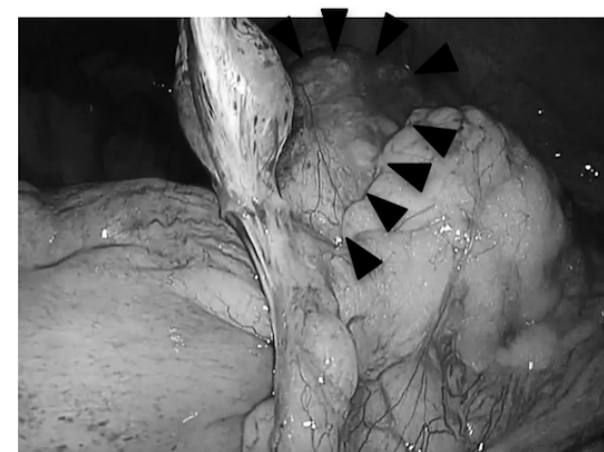

a

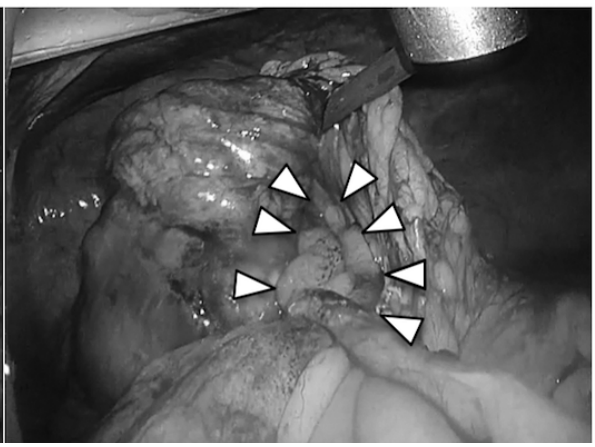

$\mathrm{b}$

Fig. 3 Intra-abdominal tumor, which is pointed with black arrow-heads, was located in the intestinal mesentery and adhered with the abdominal wall, greater omentum, and another intestinal mesentery ( a ). The distal small bowel was incarcerated in the space constituted with the tumor and adhesions around it, which is pointed with white arrow-heads (b ).

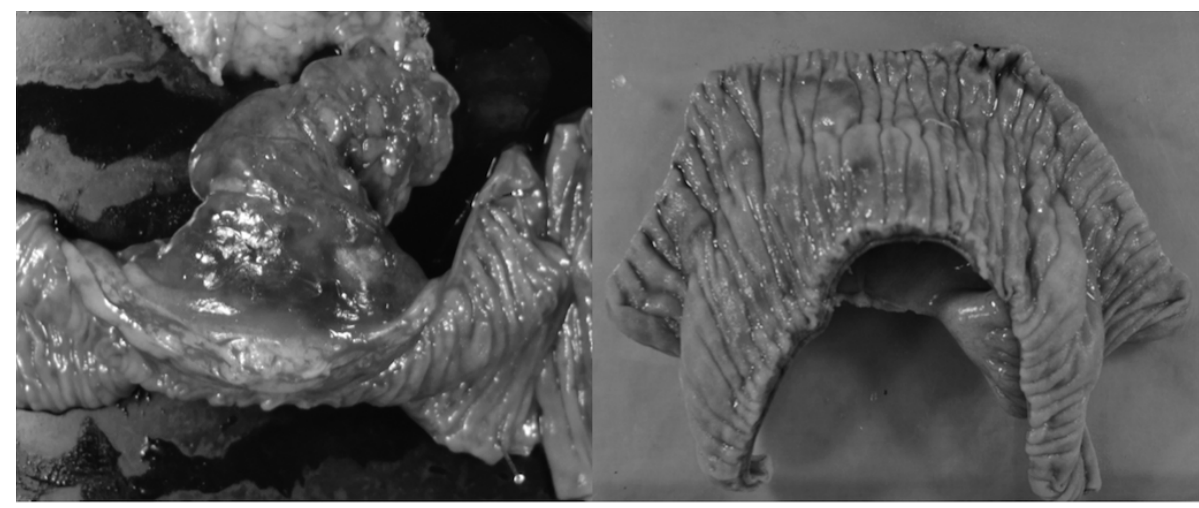

a

$\mathrm{b}$

Fig. 4 The tumor was located in the intestinal mesentery (a) and the mucosa of small bowel seemed normal ( b ).

ある．魚の生食文化と強く関連しており，本邦では比 較的経験しやすい疾患である。 その症状としては大き く 4 つあり, 胃アニサキス症・小腸アニサキス症・異 所性アニサキス症・アニサキスアレルギーである. 胃・ 小腸アニサキス症がその大半を占め, 異所性アニサキ ス症の報告は $0.85 \%$ とされ，日本の集計でも約 26,000 件中104件と極めて稀であるが，自覚症状がなく，発 見が困難であることで報告が減少している可能性があ $ろ^{12)}$ ，無症状のまま経過し，腸間膜腫瘤で発見され ることもあり ${ }^{3)}$, 今回の症例もアニサキスの感染によ り形成された腸間膜の肉芽種性腫瘤により腸閉塞に至 ったと考えられる.

異所性アニサキス症の診断においては, CT検査・
MRI検査などで炎症性腫瘤を認めることがあり，今 回の症例でも入院時の CT 検査にて腫瘤影を認めた が，特異的所見ではない.アニサキス症の特異的診断 には抗アニサキス抗体価の測定が有用であるとされて いるが4), 検査結果の判明までに時間を要することな どから有用な場面は限られる。そもそも頻度が少ない ことも併せて, 病理検査以外での診断は困難であると 考えられる. 本症例も術検体の病理検査で初めて確定 診断がなされている。医学中央雑誌で「異所性アニサ キス症, 腸管外アニサキス症, 腸閉塞」をキーワード として，1985年10月から2017年 2 月までの期間で検索 した結果, 異所性アニサキス症による腸閉塞は15例(会 議録を除く）を認めたが5) 19)，その全てが原因不明の 


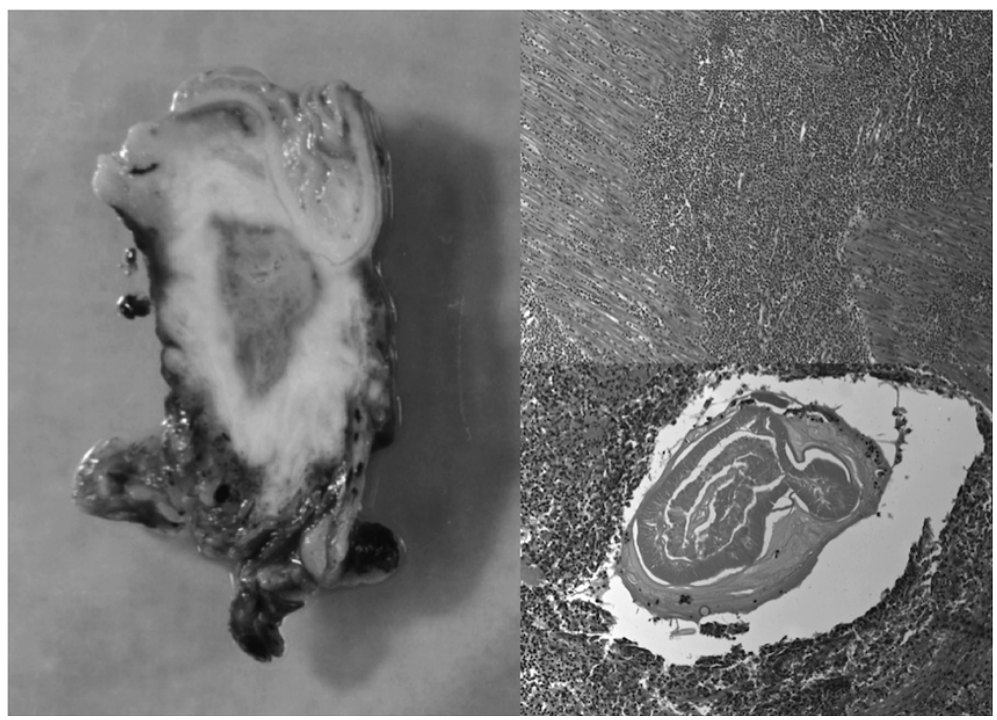

Fig. 5 The tumor was located out of the intestinal wall (a) and was an eosinophilic granuloma ( b : H.E. stain, $\times 100$ ). An Anisakis larva was found within the granuloma ( $\mathbf{c}:$ H.E. stain, $\times 100)$.

腸閉塞の診断で手術を施行されており, 術前診断が困 難であることがわかる，手術歴のない腸閉塞では，ア 二サキス症も考慮し，海産魚介類の摂食歴を確認する と診断の一助になると考える. また, 本症例では入院 時の血液検查所見で好酸球増多を認め, 寄生虫疾患の 可能性が示唆されたが, 感度・特異度ともに高いもの ではなく ${ }^{20)}$, 過去の報告でも好酸球増多を認めない症 例も多いため78814)，必ずしも診断に有用とは言えな い.

今回の症例は腹胿鏡下でイレウス解除, 小腸部分切 除を行った．腹腔鏡下イレウス解除術は1991年にBastug らに初めて報告されて以降, 本邦でも近年頻繁に 報告されている21). しかし, 腹腔鏡下手術と開腹手術 を比較した良質なランダム化試験は少なく，その適応 も定められてはいない.しかし，一つのsystematic reviewでは良好な短期予後が報告されており ${ }^{222}$, 適 応を選べば低侵襲な治療法として有用な方法と考えら れる．本症例ではイレウス管による術前加療に不応で あり，腸管拡張により視野不良になる可能性が考えら れたが, 責任病変（腫瘤）の位置が特定できていたこ とことから，腹腔鏡下でスムーズにイレウス解除術を 行うことができた，本症例をあわせると本邦で報告さ れている異所性アニサキス症による腸閉塞は16例であ
り，そのうち腹腔鏡下手術は 3 例で行われているが, すべてに打いて術後合併症は認めていない1114)。それ ぞれの報告でも病変の位置が術前から推定されてお り，異所性アニサキス症による腹腔内腫瘤のように, 術前に責任病変の位置の把握が可能である腸閉塞に は，腹腔鏡手術が有用である可能性がある。

\section{結語}

アニサキス幼虫の小腸壁外陥入に起因する腸間膜腫 瘤を契機に発症した，腸閉塞に対して腹腔鏡下手術に て治瘾を得た 1 例を経験した。異所性アニサキス症の 頻度は稀であり，術前診断はしばしば困難であるが， 腹腔内腫瘤，腸閉塞の鑑別診断として留意しておく必 要がある。

利益相反：なし

\section{文献}

1) Hochberg NS, Hamer DH : Anisakidosis : Perils of the deep. Clin Infect Dis $2010 ; 51: 806-812$

2）石倉 肇：日本における Anisakidosisの発生状況 の解析. 臨と研 $1995 ; 72: 1152-1158$

3) Cespedes M, Saez A, Rodriguez I, et al : Chronic anisakiasis presenting as a mesenteric mass. Abdom Imaging $2000 ; 25: 548-550$

4）堀野敬, 木村正美, 西村卓祐他：血清免疫学的 検査で膵アニサキス症が疑われた 1 例. 日消外会 
誌 $2007 ; 40: 186-191$

5) Masui N, Fujima N, Hasegawa $T$, et al : Small bowel strangulation caused by parasitic peritoneal strand. Pathol Int 2006 ; 56 : 345-349

6）下國達志, 青木貴徳, 大黒聖二他：消化管外ア二 サキス症による絞扼性イレウスの 1 例。日臨外会 誌 $2008 ； 69: 1373-1377$

7）中村将人, 丸山憲太郎, 古川順康他：アニサキス 虫体を核とした後腹膜好酸球性肉芽腫による絞扼 性腸閉塞症の 1 例。日臨外会誌 2001；62：2953 $-2956$

8）今井哲也, 戸田有宣, 石黒 要他：アニサキス属 幼線虫の消化管外寄生による絞扼性イレウスの 1 例. 日臨外会誌 $2004 ; 65: 966-970$

9）伊藤元博, 土屋十次, 立花 進他：PCR法にて同 定した消化管外アニサキス症による絞扼性イレウ スの 1 例. 日腹部救急医会誌 $2009 ; 29$ ：925929

10）佐藤正夫, 仁科正実, 松下 祥他：消化管外アニ サキス症による絞扼性イレウスを合併した卵巣囊 腫の 1 例. Clin Parasitol 2004；14:40-42

11）加藤博樹, 宇根範和, 小田切範晃他 : 腹腔鏡下イ レウス解除が可能であった消化管外アニサキス症 による絞扼性イレウスの 1 例. 日外科系連会誌 $2016 ; 41: 605-610$

12）北村彰英, 後藤 司, 長田啓嗣他：アニサキスと 思われる腸管線虫症の 2 手術例について，南大阪 病医誌 $1997 ; 45: 14-27$

13）新井善雄, 進藤和夫, 神谷晴夫：アニサキス様幼 虫に起因する絞扼性イレウスの 1 例。秋田医師会 誌 $1984 ; 36: 84-86$

14）村木 輝, 山本康弘, 岡村幹郎他：消化管外アニ
サキス症と推定され腹腔鏡下イレウス解除術を行 った 1 例. 日内視鏡外会誌 $2013 ; 18: 587-593$

15）松澤文彦, 蔵谷大輔, 濱口 純他：消化管外アニ サキス症による癒着性イレウスを来した 1 例。日 消外会誌 $2013 ； 46 ： 894-900$

16）泉公成, 村瀬茂, 四條隆幸他：病理診断によ り寄生虫（アニサキス）が原因と考えられたイレ ウスの 1 例. 日救急医会関東誌 $1995 ; 16 ： 592$ $-593$

17）神田光郎, 三輪高也, 武内有城他：小腸アニサキ ス症により絞扼性イレウスをきたした 2 例. 日臨 外会誌 $2006 ; 67: 2617-2620$

18）進藤 学, 櫻庭弘康, 大山 仁他：アニサキス症 による癒着性イレウスの 1 例. 道南医会誌 1996 ; $31: 62-64$

19）釡田茂幸, 藤田昌久, 新田 宙他：消化管外アニ サキス症による絞扼性イレウスの 1 例. 日臨外会 誌 $2014 ; 75: 3284-3288$

20) Khanna V, Tilak K, Mukhopadhyay C, et al : Significance of Diagnosing Parasitic Infestation in Evaluation of Unexplained Eosinophilia. J Clin Diagn Res 2015 ; 9 : DC22-24

21) Bastug DF, Trammell SW, Boland JP, et al : Laparoscopic adhesiolysis for small bowel obstruction. Surg Laparosc Endosc 1991; 1 : 259 $-262$

22) Sajid MS, Khawaja AH, Sains P, et al : A systematic review comparing laparoscopic vs open adhesiolysis in patients with adhesional small bowel obstruction. Am J Surg 2016 ; 212 : $138-$ 150

\title{
A CASE OF SMALL BOWEL OBSTRACTION CAUSED BY EXTRA-GASTROINTESTINAL ANISAKIASIS TREATED LAPAROSCOPICALLY
}

\author{
Yoshiyuki SUZUKI, Yoshimasa SHIMIZU, Tomoo SYATARI, \\ Masaki OHASHI, Nobuo TACHIKAWA and Takayuki HURUUCHI \\ Department of Surgery, Mito Red Cross Hospital
}

A 52-year-old man visited our hospital because of 2-week history of fever and diarrhea and right lower quadrant abdominal pain occurred 3 days before his visit. Abdominal CT scan showed dilatation of the small intestine and inflammatory findings and whirl sign around the jejunum. He was admitted to our hospital to observe the clinical course with a diagnosis of intestinal obstruction. As symptomatic remission was not attained by placing a long tube, exploratory laparoscopic operation was performed for diagnostic and therapeutic purposes on the $14^{\text {th }}$ hospital day. During the operation, we found an extramurally growing tumor in an intestinal mesentery where was $100 \mathrm{~cm}$ distant from the Treiz ligament and adhesions involving the tumor, abdominal wall, another intestinal mesentery, and greater omentum. A loop of the distal small bowel was incarcerated in a space constituted with the adhesions. We dissected the adhesions and resected the tumor. Pathological findings showed that the extramurally growing tumor was an eosinophilic suppurative granuloma. An Anisakis larva was found within the granuloma. For these findings, this case was diagnosed as extra-gastrointestinal anisakiasis. Although small bowel obstruction caused by small bowel anisakiasis is not uncommon, small bowel obstruction caused by extra-gastrointestinal anisakiasis like our case is rarely reported.

Key words : extra-gastrointestinal anisakiasis, ectopic anisakiasis, laparoscopic surgery 